\title{
Reviewing Effectuation and Bricolage in the Context of Social Entrepreneurship Multisector Collaborations
}

\author{
Michel $\operatorname{Rod}^{1}$ and Gemma Rod ${ }^{2}$ \\ ${ }^{I}$ Dean, Faculty of Business, University of New Brunswick (Saint John), Saint John, New Brunswick, Canada \\ ${ }^{2}$ Sprott School of Business, Carleton University, Ottawa, Canada \\ *Correspondence: Michel Rod, michel.rod@unb.ca
}

\begin{abstract}
Purpose: Traditional perspectives are insufficient for understanding/framing Social Entrepreneurship Triple Helix arrangements. This paper explores the extent to which specific alternative theoretical perspectives of entrepreneurship might be evident in the context of social entrepreneurship 'ventures' through multisector collaboration amongst university, government and private sector partners.

Design/methodology/approach: Within the past twenty years, more established economics-based views of entrepreneurial behaviour have been complemented with several alternative theoretical perspectives for entrepreneurship research; including effectuation and entrepreneurial bricolage. This conceptual paper reviews these literatures against the context of multisector collaboration within the triple helix.

Findings: Specifically, the paper discusses and illustrates the interplay of effectuation and social entrepreneurship given the fact that resource-constrained environments push social entrepreneurs to employ alternative strategies to compensate the more complex external conditions. Collaborative efforts deemed to be more social entrepreneurship in orientation appear to draw on effectuation and bricolage.

Originality/value: With an emphasis on affordable loss rather than expected returns; strategic alliances and collaboration rather than competitive analysis; exploitation of contingencies rather than exploitation of pre-existing knowledge; and controlling an unpredictable future rather than predicting an uncertain one, effectuation and bricolage in the context of social entrepreneurship requires quite different guiding policies. Not necessarily being as resource-constrained, but certainly attempting to address complex societal or social issues, multisector collaboration through social entrepreneurship appears to be a fruitful arena for the application of effectuation and bricolage.
\end{abstract}

Keywords: Effectuation, Multisector collaboration, Entrepreneurship, Triple helix, Social entrepreneurship

\section{ARTICLE INFORMATION}

Author(s): Michel Rod, Gemma Rod;

Received: 27 June 2020; Accepted: 08 July, 2020; Published: 17July, 2020; e-ISSN: 2347-4696;

Paper Id: BMN-IJBMR-2020-1;

Citation: https://doi.org/10.37391/IJBMR.080301

Webpage-link: https://ijbmr.forexjournal.co.in/archive/volume-8/ijbmr080301.html

\section{INTRODUCTION}

An ongoing focus of research interest in the field of entrepreneurship is the entrepreneurial decision-making process [1] and associated behavior [2]. Within the past twenty years, the more established economics-based views of entrepreneurial behaviour have been complemented with several alternative theoretical perspectives for entrepreneurship research [3]; including effectuation [4] and entrepreneurial bricolage [5]. Fisher [6] argues that both effectuation and bricolage reflect the following four dimensions: (1) existing resources serve as a source of entrepreneurial opportunity; (2) taking action is a mechanism for overcoming resource constraints; (3) community is a catalyst for venture emergence and growth; and (4) resource constraints are a source of creative innovation. Fisher [6] also considers how the critical elements of these emerging entrepreneurship theories translate into actual entrepreneurial behavior because it is important to focus on behaviors to make theories more accessible to practitioners.

Pattinson, et al. [7] posit that one of the central issues with being able to visualize effectuation is the continuous process of adaptation that occurs between entrepreneur and context. Pattinson, et al. [7] argue that effectuation processes are emergent and in a continuous state of becoming. Acknowledging the importance of better understanding this interplay between actor and context, the aim of this paper lies in whether the context must always be one of traditional/mainstream entrepreneurship; especially given 
recent research that suggests that effectual decision-making is effective beyond the context of uncertain environments [8]. Others have begun to explore the role that effectuation might play in contexts that, although involving innovativeness, are not the more traditional, entrepreneur-led venture creation contexts seen in the literature e.g., in the contexts of corporate R\&D [9], knowledge management [10], natural disaster response [11], and business model innovation [12], where with the latter example in particular, this paper supports attempts to increase the generalizability of effectuation to what Futterer, et al. [12] call a "theory of decision-making and action under uncertainty. Thus, it seems reasonable to explore the extent to which these alternative theoretical perspectives of entrepreneurship might be evident in such venture creation, and whether they are applicable and relevant outside the context of more traditional business venture creation, and especially in the context where entrepreneurship is occurring in the absence of entrepreneurs [13]! This is the crux of the present paper - non-traditional theories of entrepreneurship in the context of non-traditional entrepreneurship. Specifically, our interest lies in exploring why multi-sector collaboration merits more scholarly attention in the entrepreneurship literature. Not unexpectedly, as a theory of entrepreneurship however, there is a paucity of research on the applicability of entrepreneurial decision-making logics, such as effectuation, to contexts outside of entrepreneurial venture creation as in multisector collaboration, i.e., where organizations from different sectors choose to work together on a particular venture.

It is important to note at this point that in order to understand the applicability of effectuation in the context of multisector collaboration, the reader is alerted to the fact that multisector collaboration may result in the formation of new ventures, therefore, suggesting there is merit in looking at whether theory from the entrepreneurship literature can inform collaboration among organizations across the three sectors (or four in the case of the quadruple helix). It is appropriate to note that for the purposes of this paper, the term 'venture' is employed in a broad sense in that it is not constrained to mean a for-profit business/organization, but rather any form of organizing where the collaborative partners are working together in some collaborative undertaking. Thus, although 'venture' could entail the creation of a new 'business/organization', this paper suggests that it can also capture collaboration through consortia, alliances, formal partnerships and other collaborative undertakings.

As a conceptual paper, what follows is a non-systematic, grounded theoretical literature review. To conduct a comprehensive (but non-systematic) literature review, we examined peer-reviewed sources from a variety of journals using Google Scholar, Emerald Management, EBSCO, $\mathrm{ABI} /$ Inform and Business Source Complete databases. The search included keywords such as: 'effectuation', 'bricolage', 'social entrepreneurship', 'triple helix', multisector collaboration'. Articles were chosen for review based on their level of contribution to the growing field of literature surrounding effectuation and bricolage. In particular, emphasis was placed on studies that highlighted a shift away from traditional entrepreneurship and venture creation to social entrepreneurship and the context of multi-firm collaboration across the triple helix of government, industry and academia. Some key publications include the Journal of Business Venturing, Entrepreneurship Theory \& Practice, International Journal of Entrepreneurship and Innovation, Strategic Entrepreneurship Journal, International Journal of Entrepreneurial Behavior \& Research, Entrepreneurship \& Regional Development, Journal of Social Entrepreneurship and the Journal of Small Business and Enterprise Development. The search for relevant sources was extensive, but by no means exhaustive. It is important to note that this is not a 'Systematic Literature Review' (SLR), since the goal was to be thorough without necessarily subscribing to all the rules and rigour associated with systematic literature reviews.

The paper begins with an overview of effectuation, the effectual cycle, and the five principles of effectuation theory. This is followed by a discussion about the utility in exploring whether effectuation theory might have applicability outside of the context of traditional entrepreneurial venture creation specifically within the context of multisector collaboration from a more social entrepreneurship orientation. To further support the applicability of effectuation in this context, the significance of bricolage - which has been studied in social entrepreneurship [14, 15] - is also presented. As a conceptual paper, information is provided on a particular form of multisector collaboration i.e., the triple helix of academia, industry and government. This leads to a discussion of multisector collaboration as social entrepreneurship.

\section{EFFECTUATION}

Effectuation is a decision-making logic that entrepreneurs use to solve problems in new venture creation. Effectual logic is the opposite of causal logic. One uses causal logic when they have a pre-determined goal and given means to achieve this goal - there is the assumption of a predictable future [4]. Effectual logic, on the other hand, is used when the future holds greater uncertainty - one does not have a pre-determined goal, but rather goals emerge over time as a result of the changing imagination and aspirations of the entrepreneur and those with whom they interact [4]. Sarasvathy [4] notes that although the causal and effectual logics contrast one another, 
entrepreneurs can employ both forms of reasoning - at different times - depending upon which suits the circumstance better. Typically, however, effectuation is used in the beginning stages of a new venture and causation in later ones.

When using effectual logic in new venture creation, an entrepreneur begins by considering who they are (i.e., their traits and abilities), what they know (i.e., their education, training, and expertise) and whom they know (i.e., their social and professional networks) [4]. Upon doing this, the entrepreneur is able to imagine possible outcomes that can be reached; therefore, it facilitates them contemplating 'what can I do?'. From here, action is taken whereby eventually, through varied action and interaction with others, individuals commit resources and become stakeholders of the venture [16]. These commitments provide the entrepreneur with new means, and at the same time, bring new goals to light [4]. This process, shown in Figure 1, is called the effectual cycle.

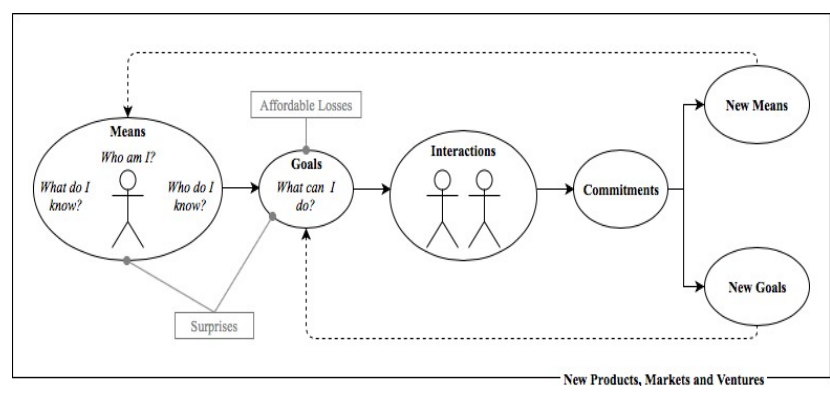

Figure 1: The Effectual cycle [17]

The effectual cycle comprises of a set of heuristics that ultimately leads the entrepreneur to the creation of new products, markets or ventures. During this process, the five principles of effectuation theory emerge, and can be applied, to aid the entrepreneur in their venture creation. The first principle, commonly referred to as bird-in-hand, encourages one to think about existing means [17]. As previously mentioned, the entrepreneur examines, and subsequently puts to use, their traits and abilities; their education, training, and expertise; as well as their networks. In using what is readily available, action can promptly be taken.

The second principle causes the entrepreneur to determine what they are willing to lose from a project. As opposed to calculating expected returns and what needs to be done to obtain said returns, one should assess what losses are conceivable, yet acceptable, if they occur. In accepting certain affordable losses, uncertainty lessens through focusing on controlling these potential downsides and creating an opportunity from them [18].
Similar to accepting losses that may lead to future opportunities, the third principle - known as the lemonade principle - suggests that one acknowledges that surprises may occur, and rather than exerting time, energy and resources to avoid them, one should leverage these contingencies by regarding their appearance as an opportunity to gain control over the emerging situation [18] and view them as a resource for shaping their goals [19].

Prior to entering a market, one can conduct a competitive analysis to better understand their position relative to competitors. Alternatively, one can establish relationships with relevant parties early on in a venture in order to co-create a market in the image of all the participants, rendering a competitive analysis unnecessary. Thus, the fourth principle of effectuation theory - termed the patchwork quilt principle involves establishing pre-commitments, i.e., partnerships with key stakeholders so that the market for which the new venture is to be a part of is less uncertain [18].

Effectual reasoning is based on the notion: "to the extent that we can control the future, we do not need to predict it" [4]. Thus, the fifth, and final, principle of effectuation theory urges the entrepreneur to focus on activities within their control. As described by Welter, Mauer and Wuebker [20], "control can be understood as a preference for directly and immediately executable actions toward an unknown future state". This has been labelled the pilot-in-the-plane principle [17]. What must be acknowledged, however, is the fact that effectuation is not completely accepted as a viable theory of entrepreneurship $[21,22]$. While it certainly has an abundance of support in the literature, there are still some who find it to be underdefined/unoriginal [23], insufficiently empirically tested [24] or insufficiently embedded in a nomological network of practical and relevant antecedents [25].

The literature concerning effectuation has greatly increased since its introduction by Sarasvathy in 2001 and we have subsequently seen several systematic literature reviews/metaanalyses of effectuation in entrepreneurship [24, 26, 27]. Researchers have taken varying approaches over the years and applied the theory of effectuation in different entrepreneurial contexts.

\section{MULTISECTOR COLLABORATION}

In today's competitive business environment, it is common to find organizations working together in order to contend more effectively in the marketplace. In fact, Majava, et al. [28] state that companies need to develop and engage in relationships with other companies to effectively serve markets and provide 
attractive offerings. Not only can inter-organizational collaboration result in increased ability to provide desirable products and services, but it can also generate greater social impact [29], as well as aid in solving complex problems. Organizations often engage in collaboration when they are faced with a problem that is too much for them to make sense of on their own [30]. For example, when encountering a 'metaproblem', which is characterized by uncertainty, complexity, and unclear boundaries, organizations regularly engage in collaborative strategies, bringing together multiple organizations, to pool a variety of expertise and resources [3134]. This idea of pooling expertise and resources is supported by the work of Loukis, et al. [35] and highlights the trend of firms shifting from solely using their own internal knowledge, resources, and skills towards collaborating with other organizations to make use of external knowledge, resources, and skills [36-38].

These collaborative relationships can cross economic sectors [39]. For example, the term 'triple helix' refers to collaboration among the public, private and academic sectors [40, 41]. Interactions and transitions between industry, government and academia can result in the creation of new innovations and organizations through collaborative funding, research and innovation processes [28]. Innovation, promoted by enabling the pooling of a wide range of expertise and resources [32-34], is one benefit of these collaborative relationships among sectors. In addition, they enable participants to view the problem from different perspectives in order to creatively exploit their differences, obtain broader stakeholder participation and ultimately realize solutions that transcend each participant's more limited capabilities/vision $[34,42]$.

Gray [43] notes that multisector collaboration, however, does present challenges given that participants can no longer take independent action to control the direction of the endeavour. Rather, their decisions and actions must be linked to those of other stakeholders. This requires integrated coordination [28]. Furthermore, such initiatives bring together participants from organizations that have varying backgrounds, philosophies, ambitions, and among which there may be an unequal distribution of power $[32,34,44]$. In such circumstances, the representatives of the organizations may view a problem differently or prefer a different solution, therefore, causing tensions to arise in participants' commitment to the collaboration [34]. The challenge is whether individuals are willing to overcome their own interests to support and develop a collaborative view or solution. Additionally, multisector collaboration tends to focus on a specific issue, or a subset of the broader issues of concern to the various stakeholders, and normally would only include a subset of the potential stakeholders that might be affected [34]. Thus, there is the potential for conflict/tension originating from differences between the collaborative versus individual organizational objectives [34, 45].

\section{TRIPLE HELIX}

The concept of the triple helix of industry, academia and government relations was established in the 1990's by Etzkowtiz [40] and Etzkowitz and Leydesdorff [41]. It conveys the change from industry-government relations dominating the Industrial Society to a growing relationship between university-industry-government in the Knowledge Society [46]. In the Knowledge Society, how information and scientific knowledge is created, shared and utilized is of the utmost importance [47]. Previously, the university was viewed as supporting innovation by providing trained personnel, the results of research and knowledge [48]. In transitioning to a Knowledge Society, however, the university has played an increasingly significant role, acting alongside industry and government [49] and becoming a source of innovation [48].

Ranga and Etzkowitz [46] describe three reasons why this enhanced role of the university came about. The first is because of the addition of what is referred to as the university 'third mission' - i.e., involvement in socio-economic development - alongside the traditional academic missions of teaching and research [46]. The second reason regards the university's capacity to provide students with new ideas, abilities and talent being viewed as an asset [46]. The third reason involves universities' ability to produce technology, thus altering the perception of them simply as a source of knowledge to a new source of technology generation [46].

The triple helix not only conveys a transformation in the relationship between university, industry and government, but also within the individual sectors whereby each increasingly "takes the role of the other" [48] and where learning, knowledge and innovation within the triple helix has the potential to sustain competitiveness for the wider economy and value for society at large [50]. This intersection of the spheres fosters innovation, better enabling the triple helix to address complex social problems, which as discussed by Hardy, et al., [34], is what many cross-sectoral collaborations are intended to do.

There is a large body of literature that discusses industry, government and academic collaboration - in relation to social issues - without necessarily referencing the triple helix. For example, Kemp [51] describes the activities of a non-profit that was created through industry, academic and government collaboration to improve disaster recovery efforts. Other examples of literatures mentioning collaboration between the 
three sectors - either all three directly or between two and one (e.g. government) indirectly - with respect to social problems are: food security $[52,53]$, healthcare $[54,55]$, water safety and security [56], and poverty reduction [57].

\section{APPLICABILITY OF EFFECTUATION TO MULTISECTOR COLLABORATION - SOCIAL ENTREPRENEURSHIP}

In reviewing the literatures on multisector collaboration and effectuation, it became evident using the grounded theoretical reviewing process that an insight was emerging - that being the idea that in looking for evidence of effectual thinking in the context of multisector collaboration, there appeared to be a link to social entrepreneurship [58]. One sees this when social entrepreneurship is found to be more innovative; especially in the context of found opportunities [59]. When multiple sectors collaborate with the goal of tackling a complex social or societal problem, it can be argued that, in this context, they are engaged in social entrepreneurship. The term collective social entrepreneurship delineates that several actors play a role in addressing a social issue [60-62], therefore, supporting the present paper's classification of the organizations collaborating across multiple sectors as social entrepreneurs. Though, the context of interest is that of instances where organizations representing multiple sectors (i.e., representatives from the academic, industry and government sectors) are collaborating in some kind of venture/undertaking in attempting to address a particular social problem. Thus, instances of social entrepreneurship that entail venture creation where 'venture' is viewed more broadly as any collaborative undertaking is the context of interest and perspective taken in the present paper. For example, Haugh [63] speaks to this in her definition of social entrepreneurship as "those activities associated with the perception of opportunities to create social value and the creation of social purpose organizations to pursue them" (p. 1). Somewhat more narrowly, Zahra, et al. [64] describe social entrepreneurship as encompassing "the activities and processes undertaken to discover, define, and exploit opportunities in order to enhance social wealth by creating new ventures..." (p. 522) - more narrowly because of their restriction of social entrepreneurship to situations of venture creation rather than more broadly as all activities and process [65]. Recall that effectuation involves entrepreneurs actively thinking about their own resources in addition to those of like-minded stakeholders when contemplating what might be possible. Interestingly, Brieger and De Clercq [66] suggest that individual-level resources play a significant role in influencing the extent to which social value creation goals are evident or emphasised.
The focus on social entrepreneurship in the context of multisector collaboration is very relevant given the fact that when multiple sectors collaborate - such as the triple helix of academia, industry and government - they have the potential to generate innovative solutions to very complex social/societal problems. This can occur when partners mutually acknowledge that they have interrelated interests and complimentary skill-sets, suggesting that working together to tackle these issues can be more successful than if any one sector attempted this individually. In fact, in their review of cross-sector collaborations, Selsky and Parker [67] note the increasing importance of these arrangements to address complex societal needs. Vurro, et al. [68] describe these crosssector social partnerships as "collaborative efforts across two or more sectors that search for more effective... approaches to solve complex social problems" (p. 39). The focal context necessitates, however, that these "approaches" to address complex social problems involves venture development, thus rationalizing why there is merit in analyzing the applicability of effectuation to such multisector collaboration.

The motive for undertaking venture creation designed to address some significant, complex social issue is often an aspiration of the social entrepreneur (e.g. the sectors) to "do something", however, the exact nature of that something is not always clear at the onset [58]. Effectual logic can thus be applied to this venture creation process since it is employed when the future is more ambiguous. Because there is uncertainty about goals, "effectual rationality lies in exercising control over what can be done with resources at hand, rather than optimizing decisions about what ought to be done given a set of predictions about what happens next" [18]. Social entrepreneurs draw from resources within their grasp [58] and create value by combining resources in new ways [69-71]. They are, therefore, epitomizing the use effectual logic. Specifically, these actions relate to the bird-in-hand principle of effectuation theory. By utilizing one's traits and abilities; their education, training, and expertise; as well as their social and professional networks - i.e., all of the resources within their grasp - they are able to determine what they can do. Social entrepreneurs, like effectuators, actively engage in collaboration and partnership development to overcome resource constraints and evolve their ideas/goals [72].

Yusuf and Sloan [58] note that a positive outcome of this behaviour is that unexpected outcomes can be "absorbed" and opportunities created through them. Unlike other decisionmaking models, such as causal reasoning, whereby there is a focus on avoiding surprises and preventing them from occurring, effectual reasoning recognizes that that not all surprises are bad, and if they occur - whether good or bad they can be leveraged and used as new inputs into the venture 
creation process [4]. Thus, by "absorbing" unexpected outcomes (or surprises), effectual thinking is being applied. Specifically, this aligns with the lemonade principle whereby the entrepreneur is acknowledging and accepting contingency by using surprises to their advantage rather than trying to avoid them, overcome them or adapt to them [17].

These opportunities created by the social entrepreneur "are a function of the idiosyncrasies of the entrepreneur, especially his or her relationships" [73]. An opportunity is a favourable situation or set of circumstances for doing something [73], such as creating a market or a venture. This notion of those individuals with whom one interacts influencing an opportunity/ a situation to do something occurs when effectual logic is employed. For example, effectual logic does not assume pre-existent markets, and therefore, following the patchwork quilt principle, encourages the entrepreneur to interact with others and build partnerships so that a market can be created that reflects the collective vision of those involved in collaborating. [4]. Thus, the entrepreneur's opportunity to create a market (i.e., to "do something") is influenced/determined by the relationships they have. Furthermore, some of those with whom the effectual entrepreneur interacts self-select into the venture creation process by making commitments to the venture, each of which results in new means and goals [17]. As resources accumulate in the collaboration, constraints begin to emerge, reducing possible changes in future goals [17]. Therefore, it can be said that it is those who come on board and collectively 'buy-in' that determine the goals of the venture [17]. Thus, the entrepreneur's opportunity for venture creation is also shaped/determined by his/her relationships.

Johannisson [74] describes the distinction between opportunity effectuation in the context of for-profit ventures versus necessity effectuation in the context of social entrepreneurship where the development of social enterprises is designed to tackle and improve specific social/societal issues. When the social entrepreneur creates a venture to address and improve a social problem, this venture may be for-profit or non-profit [75]. If creating a non-profit venture, because any profits generated through the venture's activity are reinvested into venture instead of distributed to members/shareholders, Yusuf and Sloan [58] note that what can be lost and yet still remain a viable venture must be assessed. This idea of assessing acceptable losses relates to the principle of affordable loss which suggests that the entrepreneur determine and commit in advance to what they are willing to lose [17].

To summarize, when multisector collaboration involves tackling a problem, it is because organizations from any one sector are unable to tackle the problem themselves and recognize that the nature of the problem/issue/task requires input from organizations representing multiple sectors. This is particularly true when the issue at hand concerns societal meta-problems [31-34]. Our context of interest is in the area of multisector collaboration where resulting venture creation can be viewed as social entrepreneurship rather than the more traditional, commercial profit motivated entrepreneurship. Thus, multisector collaboration involves different individuals, groups, organizations etc. committed to working together with the goal of providing benefits or added value that could not have been provided by any one sectoral partner alone [76,77].

When this collaboration transcends sectors, e.g. when it crosses academic, industry and government sector boundaries (i.e., when a triple helix is formed), there is the potential for the generation of solutions to complex social problems. In tackling these problems, and creating a venture to do so, the representatives from these sectors are acting as social entrepreneurs [69]. In reviewing the literature on multisector collaboration where social entrepreneurship is evident $[58,69$, $70,71,73,75]$, one can see indirect reference to numerous aspects of social entrepreneurs effectuating and where effectuation theory is evident. Effectuation appears, therefore, to be very applicable to multisector collaboration when the nature of the collaborative efforts involves establishing a venture to tackle complex social/societal problems i.e., it is in the realm of social entrepreneurship.

As mentioned in our introduction and as corroborated in the grounded theoretical literature review, there is a secondary aim to illustrate an additional concept - entrepreneurial bricolage as something that supports one of the core principles of effectuation. An overview of the concept is provided below, as is a discussion of bricolage in relation to effectuation and its applicability in the context of multisector collaboration; especially in the context of multisector collaborative efforts that can be seen as epitomizing the ethos of social entrepreneurship.

\section{BRICOLAGE}

The concept of bricolage was first introduced by Claude LeviStrauss [78] to differentiate the actions of an engineer and those of a bricoleur - the engineer has an intended design and focuses on obtaining the necessary tools and materials, whereas the bricoleur makes do with whatever materials are at hand. At the time of its introduction, bricolage was thus centred around the idea of "making do with what is at hand" [78]. In 2005, however, Baker and Nelson [5] offered a more integrative definition of the concept - within the context of entrepreneurship - as "making do by applying combinations of the resources at hand to new problems and opportunities" ( $p$. 
333). The three elements that make up Baker and Nelson's definition of bricolage are described below; however, it is first necessary to highlight that the context of interest is in the area of multisector collaboration where venture creation can be viewed as social entrepreneurship rather than the more traditional, commercial, profit-motivated entrepreneurship.

Servantie and Rispal [15] note that many papers investigating social entrepreneurship and its processes emphasize bricolage as an important component [79-84]. Because this paper argues that when multiple sectors collaborate (e.g. government, academia and industry) with the intent of generating solutions to complex social/societal problems - and this results in the creation of a venture - they can be classified as social entrepreneurs; therefore, bricolage - like effectuation - is very applicable to multisector collaboration.

The first element of bricolage concerns making do. This involves being actively engaged with problems or opportunities, i.e., making the most of them as opposed to contemplating whether a feasible outcome can be reached based on what is at hand [5]. Additionally, this includes the entrepreneur displaying a "willful tendency" to disregard the common limitations associated with the available resources and instead insists on testing them, trying out solutions and dealing with what results [5]. Many social entrepreneurship initiatives operate in resource-constrained environments which leads them to employ bricolage by making do with what is at hand [85].

Secondly, bricolage involves the combination of resources for new purposes. Entrepreneurs utilizing bricolage combine and reuse the resources at hand for functions in which they were not originally intended [5]. This combination of resources for new and different applications can lead the entrepreneur to innovative discoveries [5].

The third, and final, element of bricolage concerns the resources at hand. These resources can be the physical goods and materials that are readily available to the entrepreneur, as well as their skills or knowledge [5]. Thus, the resources do not strictly have to be of a tangible nature. Baker and Nelson [5] note that all of such resources also include those that the entrepreneur is able to obtain for free or at minimal cost, mainly because others often judge them as useless or inferior, but as put by Lévi-Strauss [78], "they may always come in handy" (p. 18).

In breaking down the definition of bricolage and providing a brief overview of each of its components, a clear connection can be seen between this concept and effectuation. It is known that when effectuation is used, the entrepreneur considers who they are (i.e., their traits and abilities), what they know (i.e., their education, training, and expertise), and whom they know (i.e., their social and professional networks) before action is taken [4]. Thus, effectuation processes begin by the entrepreneur focusing on the means at their disposal. This too is what an entrepreneur using bricolage does - they use the resources at hand. Additionally, when engaged in bricolage, by making do the entrepreneur is disregarding the limitations frequently associated with the resources at hand and instead utilizing them as efficiently as possible. These resource limitations are viewed as both a problem and an opportunity for the bricoleur [20]. Those utilizing bricolage will solve the problem in an innovative way using what is on hand or will combine the available resources to create an opportunity. This is essentially what the effectual entrepreneur does - in identifying existing means one is able to determine what they can do and subsequently utilizes such means to solve problems or generate opportunities in their venture creation process. Thus, the making do and resources at hand elements of bricolage are like the bird-in-hand principle of effectuation theory. The combination of resources suggested in bricolage does not directly overlap with effectuation, as do the other two elements, however, it still has relevance in our context of interest. Mair and Martí [69] define social entrepreneurship as "a process of creating value by combining resources in new ways..." (p.37). This, therefore, directly relates to the combination of resources facet of bricolage involving combining and reusing the resources readily available for new purposes.

An excellent literature review on the growing research area at the intersection between bricolage and social entrepreneurship is provided by Janssen, et al. [14] in highlighting some important issues that have yet to be fully addressed. Apart from the more obvious calls for future research to involve using different methodologies, different institutional and national contexts, and different resource constrained environments, there are two additional topics that are less overt. Firstly, there is still a need to better understand altruism, benevolence and the processes of persuasion of significant others and value creation as facets of 'social bricolage' [83]. This also ties in nicely with the aspect of effectuation that involves obtaining stakeholder buy-in/commitments. Secondly, there is merit in examining the mechanisms by which resources are enacted and mobilized at the individual and organizational levels, but also to investigate contexts where bricolage is employed in tandem with such practices as bootstrapping or strategic alliances resulting in novel or better collaboration - which once again can be seen to be supportive of effectuation and more so in the context of multisector collaboration. 


\section{DISCUSSION AND AVENUES FOR FUTURE RESEARCH}

It is generally held that the underlying drive for social entrepreneurship is the creation of social value rather than maximizing personal or shareholder wealth and that often this is characterized by pattern-breaking change or innovation via the creation of new configurations of resources or capabilities [86]. Bouchard [87] suggests that different social actors working together, and interacting can often lead to new norms, values, and rules thus challenging the status quo. Together, these concepts clearly point to a role for social actors across different sectors within the triple helix to work together collaboratively, not exclusively to create wealth, but more importantly to tackle social problems and to create social value.

We hope to have illustrated that with an emphasis on: affordable loss rather than expected returns; strategic alliances and collaboration rather than competitive analysis; exploitation of contingencies rather than exploitation of preexisting knowledge; and controlling an unpredictable future rather than predicting an uncertain one, effectuation and bricolage in the contexts of social entrepreneurship within multisector, triple helix-type collaboration is a complex set of interactions that appears to be under-researched. In addition, the underlying logic of an effectual approach to social entrepreneurship necessitates a complete policy re-think since multisector, triple helix collaborative efforts will have a significant role to play in supporting social innovation, yet there is insufficient evidence available to inform government (or any individual sector organization) regarding how they can influence, support, and facilitate appropriate multisector collaborative venture creation - where again, it is prudent to remind the reader that the intent in using the term 'venture' is to convey collaborative effort/initiative; not necessarily company creation.

A review of the multisector collaboration literature, where it assumes a social entrepreneurship orientation, would seem to indicate that these types of collaborations are enacted by entrepreneurially-minded triple helix actors that exhibit common or complementary visions and interest. In addition, the collaboration allows for multiple perspectives to co-define and co-develop the problem and potential solution by integrating disparate knowledge from across the three sectors of government, academia and industry in order to alleviate increased complexity and to share resources in tackling these larger 'meta' problems. Collaboration starts with relationships amongst key actors who all subscribe to the notion of leveraging contingencies and constantly examining and reexamining means and goals. These are all hallmarks of an entrepreneurial process that epitomises effectual logic and bricolage.

Figure 2 depicts the intersection of the triple helix as the location where social entrepreneurship efforts can occur, but it does not preclude instances of more traditional commercial entrepreneurship - where effectuation and bricolage might also be evident. What is beyond the scope of this paper is to address the nature of collaboration and/or entrepreneurship/venture creation in the intersection between government and academia, industry and academia, or government and industry; which presumably can also assume both commercial and social orientations. Our point is that when all three sectors are involved in collaborative efforts, they have the potential to tackle complex social issues and, in the process, venture creation may ensue. This multisector collaborative venture creation can often be framed as having a social entrepreneurship orientation and this, therefore, lends itself to further examination under the theoretical lenses of effectuation and bricolage, with a concomitant re-examination of the nature of the interactions within multisector collaboration to inform more traditional entrepreneurship activities. Future research could endeavour to determine the extent to which the identified 'trifecta' of 1) effectuation and bricolage in 2) social entrepreneurship/social innovation can better inform/assist in 3) triple helix-type multisector collaboration.

\section{CONCLUSION}

The contribution to the literature that our paper attempts regarding effectuation is conceptual in nature and although data are not presented, the paper "contribute(s) to the developmental state of a research program and can influence research methods used in later studies [24]. However, it is noted that effectuation is moving toward an intermediate state of research [24]. In this state, measures can be developed, and relationships tested, but it is suggested by Perry, et al. [24] that researchers also consider whether effectuation is conceptually related to other theories - which is illustrated in the present paper. Once a conceptual relationship is established, then future research could involve a more empirical approach - a concept must be sufficiently understood before it is measured and tested [24].

In addition, from an ontological, epistemological and axiological perspective, our paper supports the work of researchers like Packard [88] and Garud, et al. [89] who argue for adopting significantly more distributed and emergent views of the process of entrepreneurship such that the individuals involved in entrepreneurial behaviour rather than abstract markets are highlighted through interpretivist and 
performative lenses. In particular, Garud, et al. [89] emphasize the significance of studying entrepreneurship through a performative lens which entails an acknowledgement that the processes of entrepreneurship are "constituted, de-constituted, and re-constituted through the sayings and doings of multiple socially embedded and materially embodied actors who attempt to make meaning of unfolding processes". A performative perspective attempts to reconcile the fact that these socially embedded and materially embodied actors within various institutions possess the ability to transform current institutional configurations under conditions whereby "the very arrangements that accord agency for some deny agency to others who may want change" [89]. All of this points to the significance of better understanding bricolage and effectuation - in the context of non-commercial entrepreneurship such as that seen in triple helix, multisector collaborative social entrepreneurship undertakings.

Ultimately, bricolage, and the elements that make up this concept, can be linked to a core component of effectuation theory. Servantie and Rispal [15] argue that in social entrepreneurship, bricolage and effectuation enable a better understanding of resource scarcity, capture, and reallocation/combination such that in combination, greater social value is created - which brings us full circle to Fisher's [6] assertion that both effectuation and bricolage involve: (1) existing resources serving as a source of entrepreneurial opportunity; (2) taking action is a mechanism for overcoming resource constraints; (3) community is a catalyst for venture emergence and growth; and (4) resource constraints are a source of creative innovation. In addition, it is a relevant concept in the social entrepreneurship literatures, so it is social entrepreneurship by organizations engaged in multisector collaboration which is what this paper argues what they are doing when they address social issues, therefore, making bricolage - like effectuation - applicable to multisector collaboration.

Figure 2, is an attempt to capture the context of this paper. What has been illustrated and argued in this paper is that within the context of triple helix, multisector collaborative efforts, often times the issue(s) being addressed are comprised of the kinds of meta-problems that are of a social/societal nature and thus, venture creation assumes more of a social entrepreneurial orientation. Further, when one looks at the activities of the organizations across the sectors collaborating in these various undertakings, there is evidence of effectual behaviour and bricolage; but neither of these is exclusively restricted to the context of social entrepreneurship.

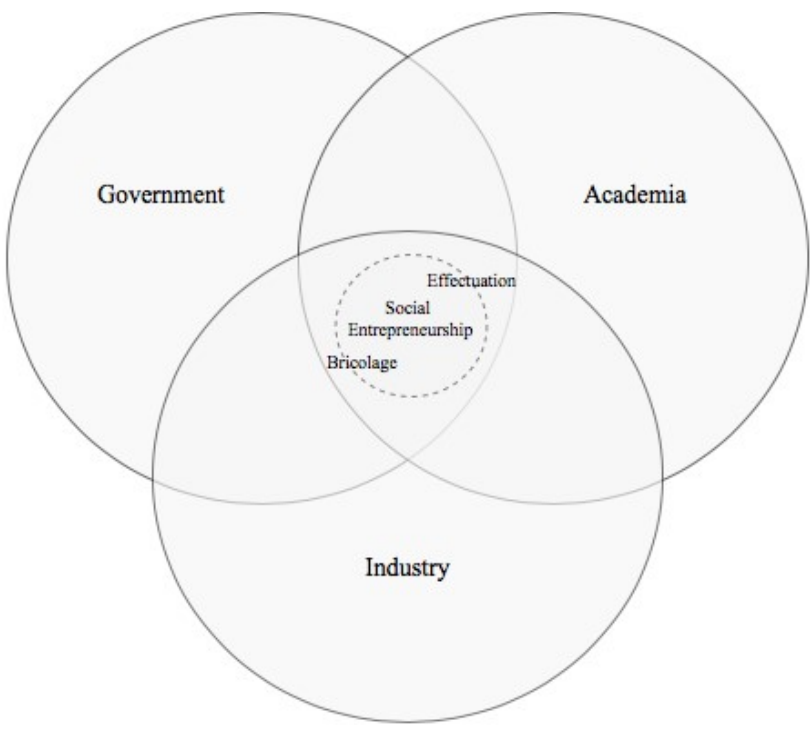

Figure 2: Effectuation and Bricolage in the context of social entrepreneurship in the Triple Helix

\section{REFERENCES}

[1] Zivdar, M., Imanipour, N., Talebi, K. and Hosseini, S. R. (2017), “An explorative study of inputs for entrepreneurs' decision-making to create new venture in a high-tech context", The International Journal of Entrepreneurship and Innovation, Vol 18 No 4, pp. 243-255.

[2] Engle, R.L., Dimitriadi, N., Gavidia, J.V., Schlaegel, C., Delanoe, S., Alvarado, I., He, X., Buame, S. and Wolff, B. (2010), "Entrepreneurial intent: A twelve-country evaluation of Ajzen's model of planned behavior", International Journal of Entrepreneurial Behaviour \& Research, Vol 16 No 1, pp. 36-57.

[3] Beckman, C., Eisenhardt, K., Kotha, S., Meyer, A. and Rajagopalan, N. (2012), "The Role of the Entrepreneur in Technology Entrepreneurship", Strategic Entrepreneurship Journal, Vol 6 No 3, pp. 203-206.

[4] Sarasvathy, S. D. (2001), What Makes Entrepreneurs Entrepreneurial? Darden Business Publishing, Charlottesville, VA, US.

[5] Baker, T. and Nelson, R. E. (2005), "Creating Something from Nothing: Resource Construction through Entrepreneurial Bricolage", Administrative Science Quarterly, Vol 50 No 3, pp. 329-366.

[6] Fisher, G. (2012), "Effectuation, Causation, and Bricolage: A behavioral comparison of emerging theories in entrepreneurship research", Entrepreneurship Theory and Practice, Vol 36 No 5, pp. 1019-1051.

[7] Pattinson, S., Ciesielska, M., Preece, D., Nicholson, J.D. and Alexandersson, A. (in press), "The "Tango Argentino": a metaphor for understanding effectuation processes", Journal of Management Inquiry.

[8] Welter, C. and Kim, S. (2018), "Effectuation under risk and uncertainty: a simulation model", Journal of Business Venturing, Vol 33 No 1, pp. $100-116$.

[9] Brettel, M., Mauer, R., Engelen, A. and Küpper, D. (2012), "Corporate effectuation- Entrepreneurial action and its impact on R\&D project performance", Journal of Business Venturing, Vol 27 No 2, pp. 167-184.

[10] Malsch, F. and Guieu, G. (in press), "How to get more with less? Scarce resources and high social ambition: effectuation as KM tool in social entrepreneurial projects", Journal of Knowledge Management. 
[11] Nelson, R. and Lima, E. (in press), "Effectuations, social bricolage and causation in the response to a natural disaster", Small Business Economics.

[12] Futterer, F., Schmidt, J. and Heidenreich, S. (2018), "Effectuation or causation as the key to corporate venture success? Investigating effects of entrepreneurial behaviors on business model innovation and venture performance", Long Range Planning, Vol 51 No 1, pp. 64-81.

[13] Liddle, J. and McElwee, G. (2019), "Theoretical perspectives on public entrepreneurship", International Journal of Entrepreneurial Behavior \& Research, Vol 25 No 6, pp. 1308-1320.

[14] Janssen, F., Fayolle, A. and Wuilaume, A. (2018), "Researching bricolage in social entrepreneurship", Entrepreneurship \& Regional Development, Vol 30 No 3-4, pp. 450-470.

[15] Servantie, V. and Rispal, M. H. (2018), "Bricolage, effectuation, and causation shifts over time in the context of social entrepreneurship", Entrepreneurship \& Regional Development, Vol 30 No 3/4, pp. 310-335.

[16] Sarasvathy, S. D. and Read, S. (2015), "Expertise and Entrepreneurship", Wiley Encyclopedia of Management, Vol 3 Entrepreneurship, pp. 1-4.

[17] Sarasvathy, S. D. (2008), Effectuation: Elements of entrepreneurial expertise. Edward Elgar Publishing, Cheltenham, U.K.

[18] Wiltbank R. and Sarasvathy, S.D. (2010), "What effectuation is not: Further development of an alternative to rational choice", paper presented at the Annual Meeting of the Academy of Management, Montreal, Canada.

[19] Lindblom, C. (1959), "The Science of "Muddling Through"', Public Administration Review, Vol 19 No 2, pp. 79-88.

[20] Welter, C., Mauer, R. and Wuebker, R. J. (2016), "Bridging Behavioral Models and Theoretical Concepts: Effectuation and Bricolage in the Opportunity Creation Framework", Strategic Entrepreneurship Journal, Vol 10 No 1, pp. 5-20.

[21] Baron, R. A. (2009), "Effectual versus predictive logics in entrepreneurial decision making: Differences between experts and novices. Does experience in starting new ventures change the way entrepreneurs think? Perhaps, but for now, "caution" is essential", Journal of Business Venturing, Vol 24 No 4, pp. 310-315.

[22] Arend, R.J., Sarooghi, H. and Burkemper, A.C. (2015), "Effectuation as Ineffectual? Applying the 3E Theory-Assessment Framework to a Proposed New Theory of Entrepreneurship", Academy of Management Review, Vol 40 No 4, pp. 630-651.

[23] Chiles, T. H., Bluedorn, A. C. and Gupta, V. K. (2007), "Beyond creative destruction and entrepreneurial discovery: A radical Austrian approach to entrepreneurship", Organization Studies, Vol 28 No 4, pp. 467-493.

[24] Perry, J. T., Chandler, G. N. and Markova, G. (2012), "Entrepreneurial Effectuation: A Review and Suggestions for Future Research", Entrepreneurship: Theory \& Practice, Vol 36 No 4, pp. 837-861.

[25] Frese, T., Geiger, I. and Dost, F. (in press), "An empirical investigation of determinants of effectual and causal decision logics in online and high-tech start-up firms", Small Business Economics.

[26] Ghorbel, F. and Boujelbène, Y. (2013), "A comprehensive literature review of effectuation theory from 1999 to 2011 ', International Journal of Entrepreneurial Venturing, Vol. 5, No. 2, pp.168-194.

[27] Read, S., Song, M. and Smit, W. (2009), "A meta-analytic review of effectuation and venture performance", Journal of Business Venturing, Vol 24 No 6, pp. 573-587.
[28] Majava, J., Isoherranen, V. and Kess, P. (2013), "Business Collaboration Concepts and Implications for Companies", International Journal of Synergy and Research, Vol 2 No 1-2, pp. 23-40.

[29] Austin, J., Stevenson, H. and Wei-Skillern, J. (2006), "Social and Commercial Entrepreneurship: Same, Different, or Both?", Entrepreneurship: Theory \& Practice, Vol 30 No 1, pp. 1-22.

[30] Seidl, D. and Werle, F. (2018), "Inter-organizational sensemaking in the face of strategic management problems: Requisite variety and dynamics of participation", Strategic Management Journal, Vol 39 No 3, pp. 830858.

[31] Trist, E. (1983), "Referent organizations and the development of interorganizational domains", Human Relations, Vol 36 No 3, pp. 269-284.

[32] Westley, F. and Vredenburg, H. (1991), "Strategic Bridging: The Collaboration between Environmentalists and Business in the Marketing of Green Products", The Journal of Applied Behavioral Science, Vol 27 No 1, pp. 65-90.

[33] Westley, F. and Vredenburg, H. (1997), "Interorganizational Collaboration and the Preservation of Global Biodiversity", Organization Science, Vol 8 No 4, pp. 381-403.

[34] Hardy, C., Lawrence, T. B. and Phillips, N. (2006), "Swimming with sharks: Creating strategic change through multi-sector collaboration", International Journal of Strategic Change Management, Vol 1 No 1/2, pp. 96-112.

[35] Loukis, E., Kyriakou, N., Pazalos, K. and Popa, S. (2017), "Interorganizational innovation and cloud computing", Electronic Commerce Research, Vol 17 No 3, pp. 379-401.

[36] Chesbrough, H. W. (2003), "The Era of Open Innovation", MIT Sloan Management Review, Vol 44 No 3, pp. 35-41.

[37] Huizingh, E. K. (2011), "Open innovation: State of the art and future perspectives", Technovation, Vol 31 No 1, pp. 2-9.

[38] West, J., Salter, A., Vanhaverbeke, W. and Chesbrough, H. (2014), "Open innovation: The next decade", Research Policy, Vol 43 No 5, pp. 805-811.

[39] Waddock, S. A. (1989), "Understanding Social Partnerships: An Evolutionary Model of Partnership Organizations", Administration \& Society, Vol 21 No 1, pp. 78-100.

[40] Etzkowitz, H. (1993), "Technology transfer: The second academic revolution", Technology Access Report, Vol 6 No 6, pp. 7-9.

[41] Etzkowitz, H. and Leydesdorff, L. (1995), "The Triple Helix -University-Industry-Government Relations: A Laboratory for Knowledge Based Economic Development", EASST Review, Vol 14 No 1. pp. 14-19.

[42] Gray, B. (1989). Collaborating: Finding Common Ground for Multiparty Problems, Jossey-Bass, San Francisco.

[43] Gray, B. (2000), "Assessing Inter-Organizational Collaboration", Faulkner, D. and De Rond, M. (Eds.), Cooperative Strategy, Oxford University Press, Oxford, pp. 243-260.

[44] Gray, B. and Hay, T.M. (1986), "Political Limits to Interorganizational Consensus and Change", The Journal of Applied Behavioural Science, Vol 22 No 2, pp. 95-112.

[45] Maguire, S., Hardy, C. and Lawrence, T. B. (2004), "Institutional entrepreneurship in emerging fields: HIV/AIDS treatment advocacy in Canada", Academy of Management Journal, Vol 47 No 5, pp. 657-679.

[46] Ranga, M. and Etzkowitz, H. (2013), "Triple Helix Systems: An Analytical Framework for Innovation Policy and Practice in the Knowledge Society", Industry and Higher Education. Vol 27 No 4, pp. 237-262. 
[47] Dinu, M. (2008), "What is the Knowledge Society?", Theoretical and Applied Economics, Vol 2 No 2, pp. 45-50.

[48] Etzkowitz, H. (2003), "Innovation in Innovation: The Triple Helix of University-Industry Government Relations", Social Science Information, Vol 42 No 3, pp. 293-337.

[49] Etzkowitz, H. (2008), The Triple Helix: University-IndustryGovernment Innovation in Action, Routledge, London.

[50] Matlay, H. and Mitra, J. (2002), "Entrepreneurship and learning: The double act in the triple helix", International Journal of Entrepreneurship and Innovation, Vol 3 No 1, pp. 7-16.

[51] Kemp, B. (2017), "Implementation of NG9-1-1 in Rural America? The Counties of Southern Illinois: Experience and Opportunities", IEEE Communications Magazine, Vol 55 No 1, pp. 152-158.

[52] Rampisela, D. A., Sjahril, R., Lias, S.A. and Mulyadi, R. (2018), "Transdisciplinary research on local community-based sago forest development model for food security and marginal land utilization in the coastal area", paper presented at 1st International Conference on Food Security and Sustainable Agriculture in The Tropics (IC-FSSAT), 24-25 October 2017, Sulawesi Selatan, Indonesia, published in IOP Conference Series: Earth and Environmental Science.

[53] Luh, Y., Jiang, W. and Chien, Y. (2014), "Adoption of geneticallymodified seeds in Taiwan", China Agricultural Economic Review, Vol 6 No 4, pp. 669-697.

[54] Ii, S. S., Fitzgerald, L., Morys-Carter, M. M., Davie, N. L. and Barker, R. (2018), "Knowledge translation in tri-sectoral collaborations: An exploration of perceptions of academia, industry and healthcare collaborations in innovation adoption", Health Policy, Vol 122 No 2, pp. 175-183.

[55] Azuma, R. and Kodama, M. (2018), "Telemedicine System Developments through Strategic Collaboration between Industry, Government and Academia", Kodama M. (Ed.) Collaborative Dynamic Capabilities for Service Innovation, Palgrave Macmillan, Cham, pp. 163202.

[56] Heringa, P. W., Horlings, E., van der Zouwen, M., van den Besselaar, P. and van Vierssen, W. (2014), "How do dimensions of proximity relate to the outcomes of collaboration? A survey of knowledge-intensive networks in the Dutch water sector", Economics of Innovation \& New Technology, Vol 23 No 7, pp. 689-716.

[57] Almeida, M., Mello, J. D. and Etzkowitz, H. (2012), "Social innovation in a developing country: invention and diffusion of the Brazilian cooperative incubator", International Journal of Technology \& Globalisation, Vol 6 No 3, pp. 206-224.

[58] Yusuf, J. and Sloan, M. F. (2015), "Effectual Processes in Nonprofit Start-Ups and Social Entrepreneurship: An Illustrated Discussion of a Novel Decision-Making Approach", American Review of Public Administration, Vol 45 No 4, pp. 417-435.

[59] Hechavarría, D.M. and Welter, C. (2015), "Opportunity Types, Social Entrepreneurship and Innovation", International Journal of Entrepreneurship and Innovation, Vol 16 No 4, pp. 237-251.

[60] Montgomery, A., Dacin, P. and Dacin, M. (2012), "Collective Social Entrepreneurship: Collaboratively Shaping Social Good", Journal of Business Ethics, Vol 111 No 3, pp. 375-388.

[61] Bacq, S. and Janssen, F. (2011), "The multiple faces of social entrepreneurship: A review of definitional issues based on geographical and thematic criteria", Entrepreneurship \& Regional Development, Vol 23 No 5/6, pp. 373-403.

[62] Choi, N. and Majumdar, S. (2014), "Social entrepreneurship as an essentially contested concept:

Opening a new avenue for systematic future research", Journal of Business Venturing, Vol 29 No 3, pp. 363-376.

[63] Haugh, H. (2005), "A research agenda for social entrepreneurship", Social Enterprise Journal, Vol 1 No 1, pp. 1-12.

[64] Zahra, S. A., Gedajlovic, E., Neubaum, D. O. and Shulman, J. M. (2009), "A typology of social entrepreneurs: Motives, search processes and ethical challenges", Journal of Business Venturing, Vol 24 No 5, pp. 519-532.

[65] Harding, R. (2004), "Social enterprise: the new economic engine?", Business and Strategy Review, Vol 15 No 4, pp. 39-43.

[66] Brieger, S. A. and De Clercq, D. (2018), 'Entrepreneurs' individuallevel resources and social value creation goals: The moderating role of cultural context", International Journal of Entrepreneurial Behavior \& Research, Vol 25 No 2, pp. 193-216.

[67] Selsky, J. W. and Parker, B. (2005), "Cross-Sector Partnerships to Address Social Issues: Challenges to Theory and Practice", Journal of Management, Vol 31 No 6, pp. 849-873.

[68] Vurro, C., Dacin, M. and Perrini, F. (2010), "Institutional Antecedents of Partnering for Social Change: How Institutional Logics Shape CrossSector Social Partnerships", Journal of Business Ethics, Vol 94 (Supplement 1), pp. 39-53.

[69] Mair, J. and Martí, I. (2006), "Social entrepreneurship research: A source of explanation, prediction, and delight", Journal of World Business, Vol 41 No 1, pp. 36-44.

[70] Newth, J. and Woods, C. (2014), "Resistance to Social Entrepreneurship: How Context Shapes Innovation", Journal of Social Entrepreneurship, Vol 5 No 2, pp. 192-213.

[71] Newth, J. (2016), "Social Enterprise Innovation in Context: Stakeholder Influence through Contestation", Entrepreneurship Research Journal, Vol 6 No 4, pp. 369-399.

[72] Dwivedi, A. and Weerawardena, J. (2018), "Conceptualizing and operationalizing the social entrepreneurship construct", Journal of Business Research, Vol 86, pp. 32-40.

[73] Corner, P. D. and Ho, M. (2010), "How Opportunities Develop in Social Entrepreneurship", Entrepreneurship: Theory \& Practice, Vol 34 No 4, pp. 635-659.

[74] Johannisson, B. (2018), "Disclosing everyday practices constituting social entrepreneuring - a case of necessity effectuation", Entrepreneurship \& Regional Development, Vol 30 No 3-4, pp. 390-406.

[75] Parris, D. L. and McInnis-Bowers, C. V. (2014), "Social Entrepreneurship Questioning the Status Quo: Waste as a Resource", Journal of Economic Issues, Vol 48 No 2, pp. 359-366.

[76] Conteh, C. (2013), "Strategic Inter-Organizational Cooperation in Complex Environments", Public Management Review, Vol 15 No 4, pp. 501-521.

[77] Sullivan, H. and Skelcher, C. (2002), Working Across Boundaries: Collaboration in Public Services, Palgrave, Basingstoke.

[78] Lévi-Strauss, C. (1996), The Savage Mind, University of Chicago Press, Chicago, IL.

[79] Bacq, S., Ofstein, L.F., Kickul, J.R. and Gundry, L.K. (2015), "Bricolage in Social Entrepreneurship", International Journal of Entrepreneurship and Innovation, Vol 16 No 4, pp. 283-289.

[80] Sunduramurthy, C., Zheng, C., Musteen, M., Francis, J. and Ryne, L. (2016), "Doing more with less, systematically? Bricolage and ingenieuring in successful social ventures", Journal of World Business, Vol 51 No 5, pp. 855-870. 
[81] Desa, G. (2012), "Resource Mobilization in International Social Entrepreneurship: Bricolage as a Mechanism of Institutional Transformation", Entrepreneurship: Theory \& Practice, Vol 36 No 4, pp. 727-751.

[82] Desa, G. and Basu, S. (2013), "Optimization or Bricolage? Overcoming Resource Constraints in Global Social Entrepreneurship", Strategic Entrepreneurship Journal, Vol 7 No 1, pp. 26-49.

[83] Di Domenico, M., Haugh, H. and Tracey, P. (2010), "Social Bricolage: Theorizing Social Value Creation in Social Enterprises", Entrepreneurship: Theory \& Practice, Vol 34 No 4, pp. 681-703.

[84] Mair, J. and Marti, I. (2009), "Entrepreneurship in and around institutional voids: A case study from Bangladesh", Journal of Business Venturing, Vol 24 No 5, pp. 419-435.

[85] Bojica, A. M., Ruiz Jiménez, J. M., Ruiz Nava, J. A., and FuentesFuentes, M. M. (2018), "Bricolage and growth in social entrepreneurship organisations", Entrepreneurship \& Regional Development, Vol 30 No 3-4, pp. 362-389.
[86] Phillips, W., Lee, H., Ghobadian, A., O'Regan, N. and James, P. (2015), "Social innovation and social entrepreneurship: a systematic review", Group \& Organization Management, Vol 40 No 3, pp. 428-461.

[87] Bouchard, M. J. (2012), "Social innovation, an analytical grid for understanding the social economy: The example of the Quebec housing sector", Service Business, Vol 6 No 1, pp. 47-59.

[88] Packard, M.D. (2017), "Where did interpretivism go in the theory of entrepreneurship?" Journal of Business Venturing, Vol 32 No 5, pp. 536549.

[89] Garud, R., Gehman, J. and Giuliani, A. (2018), "Why not take a performative approach to entrepreneurship?" Journal of Business Venturing Insights, Vol 9, pp. 60-64.

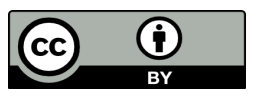

(C) 2020 by the authors. Submitted for possible open access publication under the terms and conditions of the Creative Commons

Attribution $(\mathrm{CC}$ BY) license

(http://creativecommons.org/licenses/by/4.0/). 